\title{
The Constant Annual Premium and Benefit Reserve for Four Participants in Joint Life Insurance
}

\author{
Nindita Nadilia, Nina Fitriyati*, and Irma Fauziah \\ Program Studi Matematika Fakultas Sains dan Teknologi \\ Universitas Islam Negeri Syarif Hidayatullah Jakarta \\ Email: ninditanadilia@gmail.com, \{nina.fitriyati,irma.fauziah@uinjkt.ac.id\}
}

\begin{abstract}
This research discusses the derivation of formula to calculate the constant annual premiums and the benefit reserves for joint insurance consisting of four people. We combine pure endowment insurance, lifetime insurance, and n-year term insurance. Assumed that the benefits are set at the beginning of the insurance contract, the benefit reserves are calculated using the prospective method, and the premium payment stops if one of those four participants dies. If all participants live until the end of the contract, the benefits are paid at once but if one of the participants dies, the benefits paid at the end of the contract in the form of a lifetime annuity. The formula to calculate the benefit reserves is divided into four cases i.e. the benefit reserves if one of four participants dies, the benefit reserves if two of four participants die, the benefit reserve if three of four participants die, and the benefit reserves if all participants are still alive until the end of the contract. Besides, we also present simulation to calculate the constant annual premium for four participants consist of a father ( 50 years old), a mother ( 45 years old), a son (20 years old), and a daughter (15 years old). From the simulation, we conclude that as the length of the insurance contract increases, the premium tends to decrease. The benefit reserve calculation does not have a certain tendency. It generally increases during the insurance period (the premium is still paid) and then decreases thereafter. This is valid for all cases mentioned above.
\end{abstract}

Keywords: n-year term insurance; prospective method; pure endowment insurance.

\begin{abstract}
Abstrak
Penelitian ini membahas mengenai penurunan rumus untuk menghitung premi tahunan konstan dan cadangan benefit untuk asuransi gabungan yang terdiri dari empat orang. Jenis asuransi yang digunakan adalah kombinasi antara asuransi endowment murni, asuransi seumur hidup dan asuransi berjangka $n$ tahun. Diasumsikan bahwa benefit ditetapkan di awal kontrak asuransi dan pembayaran premi berhenti jika salah seorang dari keempat peserta meninggal dunia. Jika seluruh peserta hidup sampai dengan akhir kontrak maka benefit dibayarkan secara sekaligus, namun jika salah satu dari peserta telah meninggal dunia maka benefit yang dibayarkan pada akhir tahun kontrak dalam bentuk anuitas seumur hidup. Rumus yang diperoleh untuk menghitung cadangan benefit dibagi menjadi empat kasus yaitu cadangan benefit jika satu orang meninggal dan tiga orang lainnya hidup, cadangan benefit jika dua orang meninggal dan dua orang lainnya hidup, cadangan benefit jika tiga orang meninggal dan satu orang lainnya hidup, dan cadangan benefit jika semua peserta tetap hidup sampai akhir masa kontrak. Pada akhir penelitian, disajikan simulasi perhitungan premi tahunan konstan untuk empat peserta yang terdiri dari ayah (berusia 50 tahun), ibu (45 tahun), anak laki-laki (20 tahun), dan anak perempuan (15 tahun).
\end{abstract}




\begin{abstract}
Dari simulasi diperoleh bahwa semakin lama kontrak asuransi maka premi yang dibayakan cenderung semakin kecil. Perhitungan cadangan benefit tidak memiliki kecenderungan tertentu, namun pada umumnya meningkat selama masa asuransi berlangsung (pembayaran premi masih dilakukan) kemudian menurun setelahnya. Hal ini berlaku untuk seluruh kasus yang telah dibahas pada perhitungan rumus cadangan premi.
\end{abstract}

Kata kunci: asuransi berjangka n-tahun; metode prospektif; asuransi endowment murni.

\title{
1. INTRODUCTION
}

In family life, the risk of death from one family member needs to be prepared, especially the death of the breadwinner parent. Therefore, one way to reduce financial risk is by buying an insurance program. Besides protection, insurance is also used for an investment. There are several types of insurance and one of them is life insurance.

Life insurance is a type of insurance that covers the financial risk due to someone's death or someone's life that lives too long. Life insurance contracts not only protect someone but also cover two or more people. Type of insurance that covers at least two people is called Joint life insurance [1]. The benefit is paid if one of the people covered dies during the policy length. In insurance theory, insurance participants or insured parties are required to pay premiums under insurance contracts (policies) and insurance companies are required to prepare a reserve fund to pay the participant's claim in the future.

In calculating the joint-life premium, it is necessary to assume whether the joint probability of the participants is dependent or independent. These conditions affect the calculation of joint life annuity, especially for married couples [2]. Hu [3] calculated the joint life premium under a dependent condition. Kaluszka and Okolewski [4] discussed the bound on difference life premiums for dependent and dependent conditions. Gobbi et al. [5] suggested modeling the joint life premium using Extended Marshall-Olkin (EMO) models. The premium is determined based on the interest rate: random [6] and stochastics [7]. In some countries with a majority Muslim population, the determination of the premium is influenced by several rules in the sharia system [8] [9] [10].

The determination of joint life premiums for two [11] and three people [12] have been discussed. In this research, we explain the derivation of the constant annual premium calculation and benefit reserve in joint life for the family with four participants using the prospective method and constant interest rate. We combine pure endowment insurance, lifetime insurance, and n-year term insurance. We assume that the benefits are set at the beginning of the insurance contract and the premium payment stops when one of those four participants dies. In addition, we also provide simulations for these calculations.

\section{METHOD}

\subsection{Formulation of the Constant Annual Premium}

According to the equivalence principle, the net premium is determined such that the expected value of future losses is zero at the beginning of the contract, $E(L)=0$ where $\mathrm{L}$ is losses and the premium associated to a risk $X$ must equal to its expected value i.e. $\pi[X]=E[X]$ [13]. This principle applies when an insurance policy issued. This basic principle is a healthy and fair guideline. It does not make a loss or gain either for the insurance company or the insured.

Without loss of generality, in this paper we only calculate the constant annual premium for 4 participants consist of father, mother, and two children (a boy and a girl). Let the participants' ages 
are $w, x, y$, and $z$, respectively. The premium will be paid during the contract period i.e. $n$ year, as long as all participants are still alive. There are 13 conditions about the sum of the face amount: (1) equal to $Q$ when all participants are alive until the end of the contract period, (2) equal to $R_{x y z}$ when $(w)$ dies during the contract period and the other participants live until the end of the contract period, (3) equal to $R_{w y z}$ when $(x)$ dies during the contract period and the other participants live until the end of the contract period, (4) equal to $R_{w x z}$ when $(y)$ dies during the contract period and other participants live until the end of the contract period, (5) equal to $R_{w x y}$ when $(z)$ dies during the contract period and other participants live until the end of the contract period, (6) equal to $R_{y z}$ when $(w)$ and $(x)$ die during the contract period and the other participants live until the end of the contract period, (7) equal to $R_{x z}$ when $(w)$ and $(y)$ die during the contract period and the other participants live until the end of the contract period, (8) equal to $R_{x y}$ when $(w)$ and $(z)$ die during the contract period and the other participants live until the end of the contract period, (9) equal to $R_{w z}$ when $(x)$ and $(y)$ die during the contract period and the other participants live until the end of the contract period, (10) equal to $R_{w y}$ when $(x)$ and $(z)$ die during the contract period and the other participants live until the end of the contract period, (11) equal to $R_{y z}$ when $(w)$ and $(x)$ die during the contract period and the other participants live until the end of the contract period, (12) equal to $R_{w x}$ when $(y)$ and $(x)$ die during the contract period and the other participants live until the end of the contract period, (12) equal to $R_{i}$ lifetime for $i=w, x, y, z$ when $(i)$ lives until the end of the contract period and the other participants die during the contract period, (13) equal to the present value of the premium that has been paid if all participants died during the contract period. Based on these conditions, the cash value from the constant annual premium income can be expressed by

$$
P\left(1+v \cdot p_{w x y z}+v^{2} \cdot{ }_{2} p_{w x y z}+\ldots+v^{n-1} \cdot{ }_{n-1} p_{w x y z}\right)=P\left(\ddot{a}_{w x y z: \bar{n} \mid}\right)
$$

where $P$ is an annual premium, $\ddot{a}_{w x y z: \bar{n} \mid}=\sum_{k=0}^{n-1} v^{k}{ }_{k} p_{w x y z}, p_{w x y z}$ is the probability that the person aged $w, x, y$, and $z$ will be alive after a year, and $v^{t}=\frac{1}{(i+i)^{t}}$. We assume that the probability for all persons in group to live $n$ years is equal to product of survival probabilities of each person separately, i.e. ${ }_{n} p_{w x y z}={ }_{n} p_{w} \cdot{ }_{n} p_{x} \cdot{ }_{n} p_{y} \cdot{ }_{n} p_{z}$.

The cash value from the benefits can be expressed by

$Q v^{n} \cdot{ }_{n} p_{w x y z}+R_{x y z} \sum_{m=0}^{n-1} \sum_{k=n}^{\infty} v^{k} \cdot{ }_{k} p_{x y z} \cdot{ }_{m}\left|q_{w}+R_{w y z} \sum_{m=0}^{n-1} \sum_{k=n}^{\infty} v^{k} \cdot{ }_{k} p_{w y z} \cdot{ }_{m}\right| q_{x}+$

$R_{w x z} \sum_{m=0}^{n-1} \sum_{k=n}^{\infty} v^{k} \cdot{ }_{k} p_{w x z}{ }^{\prime}\left|q_{y}+R_{w x y} \sum_{m=0}^{n-1} \sum_{k=n}^{\infty} v^{k} \cdot{ }_{k} p_{w x y} \cdot{ }_{m}\right| q_{z}+R_{y z} \sum_{m=0}^{n-1} \sum_{k=n}^{\infty} v^{k}{ }_{k} p_{y z} \cdot$

${ }_{m}\left|\boldsymbol{q}_{\overline{w x}}+R_{x z} \sum_{m=0}^{n-1} \sum_{k=n}^{\infty} v^{k} \cdot{ }_{k} p_{x z} \cdot{ }_{m}\right| q_{\overline{w y}}+R_{x y} \sum_{m=0}^{n-1} \sum_{k=n}^{\infty} v^{k} \cdot{ }_{k} p_{x y} \cdot{ }_{m} \mid q_{\overline{w Z}}+R_{w Z} \sum_{m=0}^{n-1} \sum_{k=n}^{\infty} v^{k}$

${ }_{k} p_{w z} \cdot{ }_{m}\left|q_{\overline{x y}}+R_{w y} \sum_{m=0}^{n-1} \sum_{k=n}^{\infty} v^{k} \cdot{ }_{k} p_{w y} \cdot{ }_{m}\right| q_{\overline{x z}}+R_{w x} \sum_{m=0}^{n-1} \sum_{k=n}^{\infty} v^{k} \cdot{ }_{k} p_{w x} \cdot{ }_{m} \mid q_{\overline{y z}}+$

$R_{z} \sum_{m=0}^{n-1} \sum_{k=n}^{\infty} v^{k} \cdot{ }_{k} p_{z} \cdot{ }_{m}\left|q_{\overline{w x y}}+R_{y} \sum_{m=0}^{n-1} \sum_{k=n}^{\infty} v^{k} \cdot{ }_{k} p_{y} \cdot{ }_{m}\right| q_{\overline{w x z}}+R_{x} \sum_{m=0}^{n-1} \sum_{k=n}^{\infty} v^{k} \cdot{ }_{k} p_{x} \cdot$

${ }_{m}\left|q_{\overline{w y z}}+R_{w} \sum_{m=0}^{n-1} \sum_{k=n}^{\infty} v^{k} \cdot{ }_{k} p_{w} \cdot{ }_{m}\right| q_{\overline{x y z}}+P(I A)^{1}{ }_{w x y z: \bar{n} \mid}=Q \cdot A_{w x y z: \bar{n}}+R_{x y z}{ }_{n} \mid \ddot{a}_{x y z} \cdot{ }_{n} q_{w}+$

$\boldsymbol{R}_{w y z}{ }_{n}\left|\ddot{a}_{w y z}{ }_{n} \boldsymbol{q}_{x}+\boldsymbol{R}_{w x z}{ }_{n}\right| \ddot{a}_{w x z} \cdot{ }_{n} q_{y}+R_{w x y}{ }_{n}\left|\ddot{a}_{w x y} \cdot{ }_{n} q_{z}+R_{y z}{ }_{n}\right| \ddot{a}_{y z} \cdot{ }_{n} q_{\overline{w x}}+$

$\boldsymbol{R}_{x z}{ }_{n}\left|\ddot{a}_{x z} \cdot{ }_{n} q_{\overline{w y}}+R_{x y}{ }_{n}\right| \ddot{a}_{x y} \cdot{ }_{n} q_{\overline{w z}}+R_{w z}{ }_{n}\left|\ddot{a}_{w z} \cdot{ }_{n} q_{\overline{x y}}+R_{w y}{ }_{n}\right| \ddot{a}_{w y}{ }_{n} q_{\overline{x z}}+R_{w x}{ }_{n} \mid \ddot{a}_{w x} \cdot$

${ }_{n} q_{\overline{y z}}+R_{z} \cdot{ }_{n}\left|\ddot{a}_{z} \cdot{ }_{n} q_{\overline{w x y}}+R_{y} \cdot{ }_{n}\right| \ddot{a}_{y} \cdot{ }_{n} q_{\overline{w x z}}+R_{x} \cdot{ }_{n}\left|\ddot{a}_{x} \cdot{ }_{n} q_{\overline{w y z}}+R_{w} \cdot{ }_{n}\right| \ddot{a}_{w} \cdot{ }_{n} q_{\overline{x y z}}+$

$P(I A)^{1}{ }_{w x y z: \bar{n} \mid}$. 
According to the equivalence principle, the premium can be calculated by

$$
\begin{aligned}
P\left(\ddot{a}_{w x y z: \bar{n} \mid}\right)= & Q A_{w x y z: \bar{n}}+R_{x y z}{ }_{n}\left|\ddot{a}_{x y z} \cdot{ }_{n} q_{w}+R_{w y z}{ }_{n}\right| \ddot{a}_{w y z} \cdot{ }_{n} q_{x}+R_{w x z} \cdot{ }_{n} \mid \ddot{a}_{w x z} \cdot{ }_{n} q_{y}+ \\
& R_{w x y}{ }_{n}\left|\ddot{a}_{w x y} \cdot{ }_{n} q_{z}+R_{y z} \cdot{ }_{n}\right| \ddot{a}_{y z} \cdot{ }_{n} q_{\overline{w x}}+R_{x z} \cdot{ }_{n}\left|\ddot{a}_{x z} \cdot{ }_{n} q_{\overline{w y}}+R_{x y} \cdot{ }_{n}\right| \ddot{a}_{x y} \cdot \\
& { }_{n} q_{\overline{w z}}+R_{w z} \cdot{ }_{n}\left|\ddot{a}_{w z} \cdot{ }_{n} q_{\overline{x y}}+R_{w y}{ }_{n}\right| \ddot{a}_{w y} \cdot{ }_{n} q_{\overline{x z}}+R_{w x}{ }_{n} \mid \ddot{a}_{w x} \cdot{ }_{n} q_{\overline{y z}}+ \\
& R_{z} \cdot{ }_{n}\left|\ddot{a}_{z} \cdot{ }_{n} q_{\overline{w x y}}+R_{y} \cdot{ }_{n}\right| \ddot{a}_{y} \cdot{ }_{n} q_{\overline{w x z}}+R_{x} \cdot{ }_{n}\left|\ddot{a}_{x} \cdot{ }_{n} q_{\overline{w y z}}+R_{w} \cdot{ }_{n}\right| \ddot{a}_{w} \cdot{ }_{n} q_{\overline{x y z}}+ \\
& P(I A)^{1}{ }_{w x y z: \bar{n} \mid} .
\end{aligned}
$$

Therefore, the constant annual premium for the joint life insurance for the participants aged $w, x, y$, and $z$ is:

$$
\begin{aligned}
P= & \frac{1}{\ddot{a}_{w x y z \bar{n} \mid}-(I A)^{1}{ }_{w x y z: \bar{n} \mid}}\left(Q A_{w x y z: \bar{n}}+R_{x y z}{ }_{n}\left|\ddot{a}_{x y z} \cdot{ }_{n} q_{w}+R_{w y z}{ }_{n}\right| \ddot{a}_{w y z} \cdot{ }_{n} q_{x}+R_{w x z}{ }_{n} \mid \ddot{a}_{w x z}\right. \\
& { }_{n} q_{y}+R_{w x y}{ }_{n}\left|\ddot{a}_{w x y} \cdot{ }_{n} q_{z}+R_{y z} \cdot{ }_{n}\right| \ddot{a}_{y z} \cdot{ }_{n} q_{\overline{w x}}+R_{x z} \cdot{ }_{n}\left|\ddot{a}_{x z} \cdot{ }_{n} q_{\overline{w y}}+R_{x y} \cdot{ }_{n}\right| \ddot{a}_{x y} \cdot{ }_{n} q_{\overline{w z}}+ \\
& R_{w z} \cdot{ }_{n}\left|\ddot{a}_{w z} \cdot{ }_{n} q_{\overline{x y}}+R_{w y} \cdot{ }_{n}\right| \ddot{a}_{w y} \cdot{ }_{n} q_{\overline{x z}}+R_{w x} \cdot{ }_{n}\left|\ddot{a}_{w x} \cdot{ }_{n} q_{\overline{y z}}+R_{z} \cdot{ }_{n}\right| \ddot{a}_{z} \cdot{ }_{n} q_{\overline{w x y}}+ \\
& \left.R_{y} \cdot{ }_{n}\left|\ddot{a}_{y} \cdot{ }_{n} q_{\overline{w x z}}+R_{x} \cdot{ }_{n}\right| \ddot{a}_{x} \cdot{ }_{n} q_{\overline{w y z}}+R_{w} \cdot{ }_{n} \mid \ddot{a}_{w} \cdot{ }_{n} q_{\overline{x y z}}\right) .
\end{aligned}
$$

The number of insurance participants determines the value of the premium, the more the number of insurance participants, the greater the premium paid [12].

\subsection{Formulation of the Benefit Reserve}

The benefits reserve is a fund that is reserved by insurance companies to pay obligations in the future [14]. For joint life with contract period $n$, the benefit reserve is calculated using a combination between the prospective method and the following cases [15]. Based on 13 conditions above, we formulate the benefits reserve for one of the participants who died during the contract period and the other participants live until the end of the contract period. For example, $(w)$ died during the contract period. The benefits reserve for the $t$-th year, $t \leq n$, is ${ }_{t}^{q} V=R_{x y z} \times{ }_{n-t} \mid \ddot{a}_{x+t, y+t, z+t}$. For the $t$-th year, $t>n$, the benefits reserve is ${ }_{t} V=R_{x y z} \times \ddot{a}_{x+t, y+t, z+t}$.

The benefits reserve for two participants died during the contract period and the other participants live until the end of the contract period. For example, $(w)$ and $(x)$ died during the contract period. The benefits reserve for the $t$-th year, $t \leq n$, is ${ }_{t}^{q} V=R_{y z} \times{ }_{n-t} \mid \ddot{a}_{y+t, z+t}$. For the $t$-th year, $t>$ $n$, the benefits reserve is ${ }_{t}^{q} V=R_{y z} \times \ddot{a}_{y+t, z+t}$.

The benefits reserve for three participants died during the contract period and the other participants live until the end of the contract period. For example, only $(z)$ who still alive until the end of the contract period. The benefits reserve for the $t$-th year, $t \leq n$, is ${ }_{t}^{q} V=R_{z} \times_{n-t} \mid \ddot{a}_{z+t}$. For the $t$ th year, $t>n$, the benefits reserve is ${ }_{t}^{q} V=R_{z} \times \ddot{a}_{z+t}$.

The benefits reserve for all participants alive until the end of contract period, for the $t$-th year is

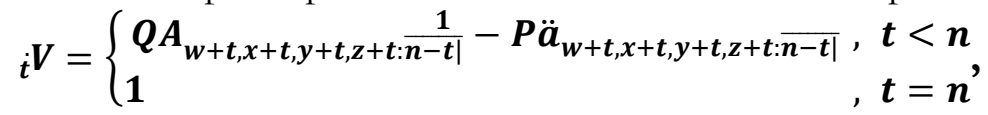

where $A_{w+t, x+t, y+t, z+t: \frac{1}{n-t \mid}}$ is the present value of single premium of pure endowment and $P \ddot{a}_{w+t, x+t, y+t, z+t: \overline{n-t \mid}}$ is the premium paid.

\section{SIMULATION RESULTS}

We use simulation to calculate the constant premium and the benefit reserve for joint life from a family that consists of a father $(w)$ aged 50 years, a mother $(x)$ aged 45 years, a son $(y)$ aged 20 years, and a daughter $(z)$ aged 15 years. The contract period $(n)$ is $1-10$ years. We assume a constant interest rate of $i=5 \%$ during the contract period. We use Indonesian Mortality Table 2011 [16] to calculate 
the joint probability of participants. To facilitate the calculation of premiums, table 1 provides multiplier factor coefficients calculated based on equation (1) with benefit $Q, R_{x y z}=R_{w y z}=R_{w x z}=$ $R_{w x y}=R_{1}, R_{y z}=R_{x z}=R_{x y}=R_{w z}=R_{w y}=R_{w x}=R_{2}, R_{w}=R_{y}=R_{x}=R_{z}=R_{3}$.

Table 1. The multiplier factor coefficients to calculate the constant annual premium for $n=1,2, \ldots, 10$ years.

\begin{tabular}{ccccc}
\hline $\begin{array}{c}n \\
\text { (year) }\end{array}$ & $A_{1}$ & $A_{2}$ & $A_{3}$ & $A_{4}$ \\
\hline 1 & 0.952012428 & 0.118701952 & 0.000273872 & $1.65 \mathrm{E}-07$ \\
\hline 2 & 0.464180848 & 0.121936760 & 0.000598770 & $7.59 \mathrm{E}-07$ \\
\hline 3 & 0.301708500 & 0.125332299 & 0.000985935 & $1.98 \mathrm{E}-06$ \\
\hline 4 & 0.220441911 & 0.128442991 & 0.001438639 & $4.05 \mathrm{E}-06$ \\
\hline 5 & 0.171713527 & 0.131282656 & 0.001961859 & $7.24 \mathrm{E}-06$ \\
\hline 6 & 0.139248783 & 0.133772162 & 0.002567460 & $1.18 \mathrm{E}-05$ \\
\hline 7 & 0.116073950 & 0.135892185 & 0.003229192 & $1.81 \mathrm{E}-05$ \\
\hline 8 & 0.098701657 & 0.137694254 & 0.003985779 & $2.64 \mathrm{E}-05$ \\
\hline 9 & 0.085194740 & 0.146617996 & 0.004838592 & $3.72 \mathrm{E}-05$ \\
\hline 10 & 0.074391256 & 0.140369344 & 0.005796381 & $5.09 \mathrm{E}-05$ \\
\hline
\end{tabular}

where $A_{1}=\frac{A_{w x y z: \bar{n}}}{\ddot{a}_{w x y z: \bar{n} \mid}-(I A)^{1}{ }_{w x y z: \bar{n} \mid}}, A_{2}=\frac{{ }_{n}\left|\ddot{a}_{x y z} \cdot{ }_{n} q_{w}+{ }_{n}\right| \ddot{a}_{w y z} \cdot{ }_{n} q_{x}+{ }_{n}\left|\ddot{a}_{w x z} \cdot{ }_{n} q_{y}+{ }_{n}\right| \ddot{a}_{w x y} \cdot{ }_{n} q_{z}}{\ddot{a}_{w x y z: \bar{n} \mid}-(I A)^{1}{ }_{w x y z: \bar{n} \mid}}$, $A_{3}=\frac{{ }_{n}\left|\ddot{a}_{y z} \cdot{ }_{n} q_{\overline{w x}}+{ }_{n}\right| \ddot{a}_{x z} \cdot{ }_{n} q_{\overline{w y}}+{ }_{n}\left|\ddot{a}_{x y} \cdot{ }_{n} q_{\overline{w z}}+{ }_{n}\right| \ddot{a}_{w z} \cdot{ }_{n} q_{\overline{x y}}+{ }_{n}\left|\ddot{a}_{w y} \cdot{ }_{n} q_{\overline{x z}}+{ }_{n}\right| \ddot{a}_{w x} \cdot{ }_{n} q_{\overline{y z}}}{\ddot{a}_{w x y z: n \mid}-(I A)^{1}{ }_{w x y z: \bar{n} \mid}}$, and $A_{4}=\frac{{ }_{n}\left|\ddot{a}_{z} \cdot{ }_{n} q_{\overline{w x y}}+{ }_{n}\right| \ddot{a}_{y} \cdot{ }_{n} q_{\overline{w x z}}+{ }_{n}\left|\ddot{a}_{x} \cdot{ }_{n} q_{\overline{w y z}}+{ }_{n}\right| \ddot{a}_{w} \cdot{ }_{n} q_{\overline{x y z}}}{\ddot{a}_{w x y z: \bar{n} \mid}-(I A)^{1}{ }_{w x y z: \bar{n} \mid}}$.

For example: let $Q=$ Rp. 10millions, $R_{1}=$ Rp. 20millions, $R_{2}=$ Rp. 30millions, and $R_{4}=$ Rp. 40millions. For $n=4$ years, the constant premium for joint life is $P=0.220441911 Q+$ $0.128442991 R_{1}+0.001438639 R_{2}+5.04 \mathrm{E}-06 R_{3}=R p .4,816,600.02$ per year. The corresponding annual premium for the benefits for different contract period $n=1,2, \ldots, 10$ are shown in Table 2 .

Table 2. The constant annual premium for benefit for contract period $n=1,2, \ldots, 10$ years.

\begin{tabular}{cc}
\hline$n$ (year) & The Annual Premium (Rp.) \\
\hline 1 & $11.902 .386,09$ \\
\hline 2 & $7.098 .537,14$ \\
\hline 3 & $5.553 .388,18$ \\
\hline 4 & $4.816 .600,02$ \\
\hline 5 & $4.401 .933,90$ \\
\hline 6 & $4.145 .428,39$ \\
\hline 7 & $3.976 .183,25$ \\
\hline 8 & $3.861 .531,30$ \\
\hline 9 & $3.930 .951,92$ \\
\hline 10 & $3.727 .226,88$ \\
\hline
\end{tabular}


Table 3 shows the constant annual premium for one unit benefit for all 13 conditions above and $n=1,2, \ldots, 10$ years. According to this table, the annual premium will be cheaper when the contract period is longer.

Table 3. The constant annual premium with benefit is 1 unit and $\boldsymbol{n}=\mathbf{1}, \mathbf{2}, \ldots, \mathbf{1 0}$ years.

\begin{tabular}{cc}
\hline$n$ & The Annual Premium \\
\hline 1 & 1.070988 \\
\hline 2 & 0.5867171 \\
\hline 3 & 0.4280287 \\
\hline 4 & 0.3503276 \\
\hline 5 & 0.3049653 \\
\hline 6 & 0.2756002 \\
\hline 7 & 0.2552135 \\
\hline 8 & 0.2404081 \\
\hline 9 & 0.2366885 \\
\hline 10 & 0.2206079 \\
\hline
\end{tabular}

The benefit reserves for one of the participants died during the contract period. Table 4 illustrates the benefit reserve for $n=10$ years with benefit is 1 unit where $(w)$ died during the contract period. Figure 1 illustrates the benefit reserve for 4 cases where $(w),(x),(y)$, or $(z)$ died during the contract period. In general, benefits reserves have almost the same pattern for all conditions, which tends to increase during the premium payment period. The highest peak of benefit reserves occurs at the end of the contract period and then tends to fall thereafter. Figure 2 illustrates the benefit reserve based on the length of the contract period for the case (1). It appears that longer contract period tends to generate higher benefit reserves.

Table 4. The benefit reserve for $n=10$ years and the benefit $R_{x y z}=1$ unit where $(w)$ died during the contract period.

\begin{tabular}{cc}
\hline$t$ & $t V$ \\
\hline 1 & 6,901037 \\
\hline 2 & 7,528613 \\
\hline 3 & 8,195377 \\
\hline 4 & 8,903198 \\
\hline 5 & 9,654074 \\
\hline 6 & 10,45015 \\
\hline 7 & 11,29368 \\
\hline 8 & 12,18701 \\
\hline 9 & 13,13249 \\
\hline 10 & 14,13249 \\
\hline$\vdots$ & $\vdots$ \\
\hline 65 & 1,229337 \\
\hline 66 & 1 \\
\hline
\end{tabular}




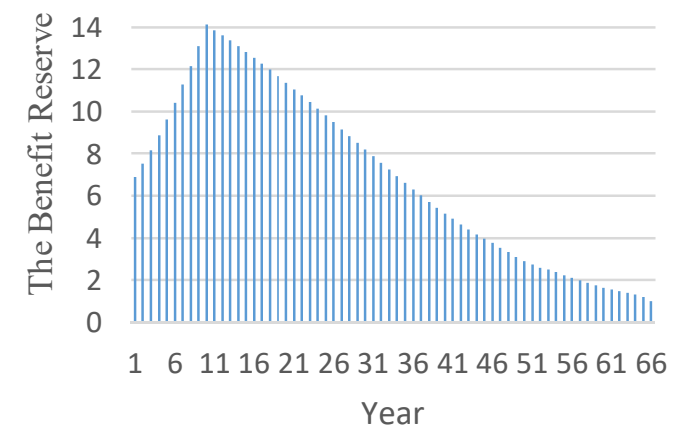

(a)

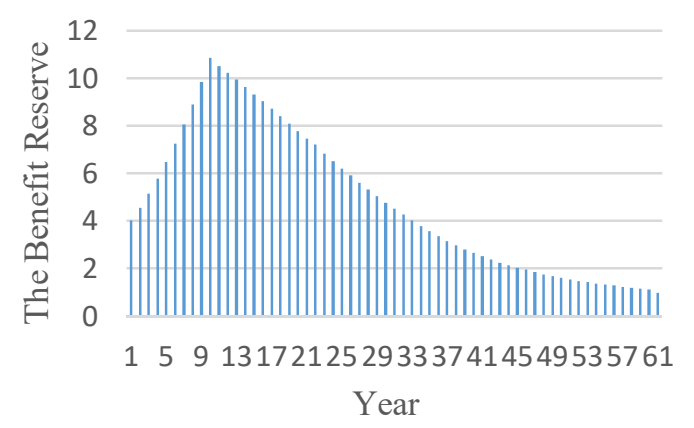

(c)

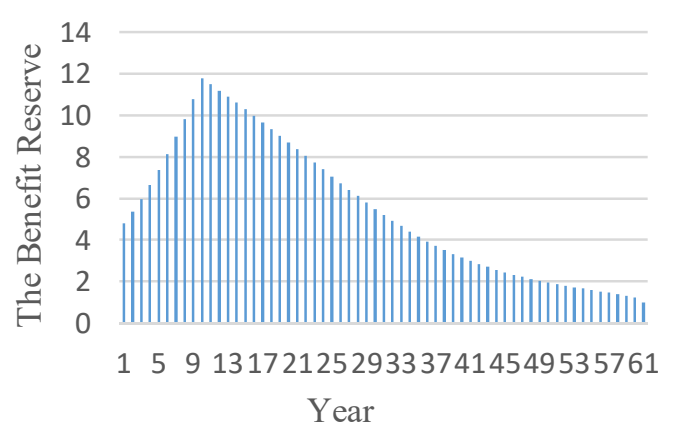

(b)

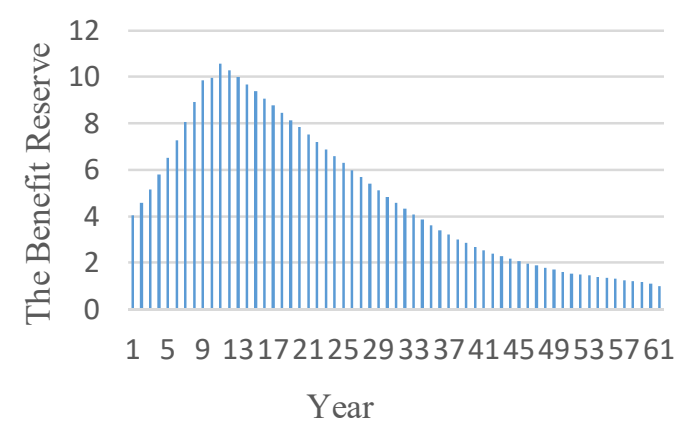

(d)

Figure 1. The benefit reserve for one of the participants died during the contract period for one unit benefit and $\boldsymbol{n}=\mathbf{1 0}$ years where $(\boldsymbol{w}),(\boldsymbol{x}),(\boldsymbol{y})$, or (z) died during the contract period, respectively (a)-(d).

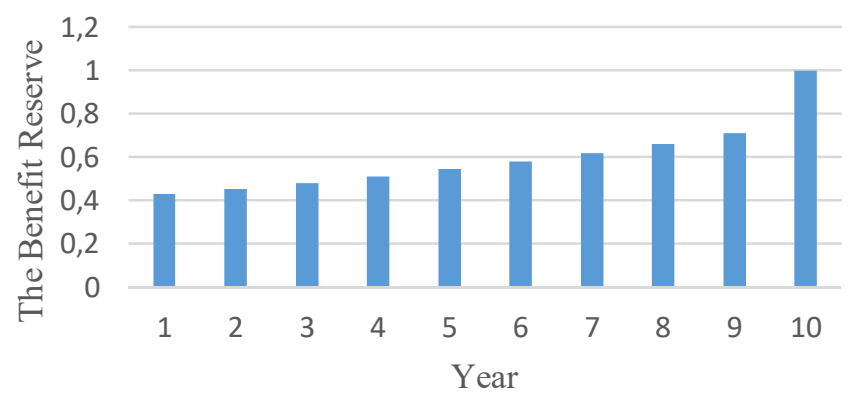

Figure 2. The benefit reserve based on the length of the contract period for all participants are still alive until the end of the contract period.

\section{CONCLUSION}

This research succeeds in formulating the calculation of constant annual premiums in joint life insurance for a family with four participants. It is assumed that the joint life probability between the participants is independent. Based on the simulation results, the constant annual premium in the joint life insurance will decrease if the insurance contract period is longer. Besides, the formulation of the benefit reserve for four participants is calculated using a prospective method by considering several cases based on the number of participants who died during the contract period. For all cases, the 
benefit reserve will increase as long as the premium is still paid (the insurance contract is still valid) with the maxima value at the end of the contract period and decrease thereafter.

\section{REFERENCES}

[1] A. Matvejevs and A. Matvejevs, "Insurance Models for Joint Life an Last Survivor Benefits," Informatica, vol. 12 No.4, pp. 547-558, 2001.

[2] J. Brown and J. Poterba, "Joint life annuities and annuity demand by married couples," Journal of Risk \& Insurance, vol. 67, no. 4, pp. 527-554, 2000.

[3] Y. Hu, "Calculations about premiums of joint life insurance under dependent conditions," in The 2nd International Conference on Information Science and Engineering, Hangzhou, China, 2010.

[4] M. Kaluszka and A. Okolewski, "A note on multiple life premiums for dependent lifetimes dependent lifetimes," Insurance: Mathematics and Economics, vol. 57, pp. 25-30, 2014.

[5] F. Gobbi, N. Kolev and S. Mulinacci, "Joint Life Insurance Pricing Using Extended MarshallOlkin Models," ASTIN Bulletin: The Journal of the LAA, vol. 49, no. 2, pp. 409-432, 2019.

[6] L. Wang, J. Zhao and D. Yang, "Joint-life insurance under random rates of interest," Dalian Ligong Daxue Xuebao/Journal of Dalian University of Technology, vol. 47, no. 6, 2007.

[7] L. Chen, "Analysis of Joint Life Insurance with Stochastic Interest Rates," Simon Fraser University, 2010.

[8] O. Kurniandi, "Stochastic Models for Premium Calculation under Syariah Law," PT. MAA Life Assurance, Indonesia.

[9] P. Ghazali, I. Mohd, M. Mamat and W. Ahmad, "Mathematical Modelling in Family Takaful," Journal of Applied Sciences, vol. 11, pp. 3381-3388, 2011.

[10] K. Khotimah, Mahmudi and N. Fitriyati, "Calculation and Management of Premium Funds in Sharia Insurance based on Langevin Type Model of Return on Investment," InPrime: Indonesian Journal of Pure and Applied Mathematics, vol. 1, no. 2, pp. 128-135, 2019.

[11] N. L. P. R. Dewi, I. N. Widana and D. P. E. Nilakusmawati, "Penentuan Cadangan Premi untuk Asuransi Joint Life," E-Jurnal Matematika, vol. 5, no. 1, pp. 32-37, 2016.

[12] T. Y. Bhuana, I. N. Widana and L. P. I. Harini, "Menentukan Premi Tahunan Untuk Tiga Orang Pada Asuransi Jiwa Hidup Gabungan," E-Jurnal Matematika, vol. 4 , no. 4, pp. 195-200, 2015.

[13] P. L. Ramos, "Premium Calculation in Insurance Activity," Journal of Statistics \& Management Systems, vol. 20, no. 1, pp. 39-65, 2017.

[14] T. Futami, Matematika Asuransi Jiwa, Tokyo: Oriental Life Insurance Cultural Development Center, 1993.

[15] N. K. Sukanasih, I. N. Widana and K. Jayanegara, "Cadangan Premi Asuransi Joint-Life dengan Suku Bunga Tetap dan Berubah Secara Stokastik," E-Jurnal Matematika, vol. 7, no. 2, pp. 79-87, 2018.

[16] T. AAJI, "Tabel Mortalita III-2011," Asosiasi Asuransi Jiwa Indonesia (AAJI), 2012. 